\title{
An Evaluation of the Economic Impact of Slum Settlement Relocation Programs on The Bengawan Solo Riverbank In Indonesia
}

\author{
Doris Kokutungisa Ishenda, Shi Guoqing \\ School of Public Administration \\ Hohai University \\ Nanjing China
}

\begin{abstract}
Relocation or resettlement is an alternative to provide opportunities for people who live in slums where the occupation of the land is illegal or who live in a disaster-prone environment to reorganize and continue their lives in a new place. This study evaluates and assesses the success of the implementation of the relocation program carried out on the Bengawan Solo Riverbank. The evaluation conducted in this study is a summative evaluation. From an economic perspective, the relocation program carried out on the banks of the Bengawan Solo had no impact in terms of improving the economic conditions of the relocated community. The relocation program is thus considered unsuccessful in improving the economy of the relocated community.
\end{abstract}

Keywords: Economic Impact, Slum, Relocation, Riverbank

\section{Introduction}

The development of housing and settlements in Indonesia, especially in urban areas, cannot be separated from the population growth and development activities in the city. Urban population growth is influenced by two factors, natural growth and urbanization (Djoko Sujarto, 2002). Significant increase in population occurs in big cities such as Jakarta, Bandung, Surabaya, Yogyakarta, Semarang and others; this happens because people are attracted to opportunities that exist in them. Economically, the city is considered able to meet the necessities of life such as ease in obtaining work. In addition to that, the ease of accessibility and the high level of public services make some people decide to migrate to the city with the assumption that the city provides a guarantee and a better standard of living. Population growth from rural to urban migration will lead to settlement problems, especially the problem of squatter settlements or slum areas that develop in various cities and cause a decline in the quality of settlements (Bintarto, 1987; Desmaniar, 2009). Population growth results in reduced availability of land for future settlements. The rapid development of the population strains the ability of the city to provide adequate public services, resulting in the emergence of shantytowns and slums (Uar, 2016).

Slums in Indonesian cities are usually inhabited by poor people who are unable to access adequate housing. The inability of the poor to access proper housing forces them to live in a slum environment with inadequate basic facilities and infrastructure. These slum dwellers occupy land illegally as these lands are either abandoned state land or land around riverbanks, railroad lines, industrial zones and economic and service centers (Turner, 1987).

A slum environment consists of crowded conditions of residence or place of residence where the area of the house is not proportional to the number of occupants. The house functions merely as a place of rest and protection from heat, cold, and rain. In irregular settlement systems where land is not owned by residents, there are inadequate supplies of social amenities such as schools and clinics (Bianpoen, 1991; Haning, 2007), the unavailability of facilities such as sanitation, landfills and poor quality of drinking water. Relocation or resettlement is an alternative to provide opportunities for people who live in slums where the occupation of the land is illegal or who live in a disaster-prone environment to reorganize and continue their lives in a new place.

The relocation program in Surakarta City has been carried out since 2008 with the target of moving 1571 households. The settlements that were the target of the relocation program are situated on the banks of the Solo River and the Begawan Solo River tributaries. The relocation program is done by giving assistance to the community to be relocated with the budgeted amount of Rp. 22.3 million as indicated in the Surakarta City relocation program technical guidelines. It should be noted that the success of the settlement relocation program is not only limited to moving the settlement to a new settlement location, but the relocation program was expected to improve the conditions in the new location (Puput \& Chen, 2018). Better conditions were to include improvements in the physical and social conditions of the settlement, so as to create a new environment of sustainable settlements (De Wet, 2002). This study evaluates and assesses the success of the implementation of the relocation program carried out on the banks of Bengawan Solo. 
It is hoped that the findings and policy suggestions made in this study will be very useful in future reevaluation and improvement of the current relocation program in Indonesia.

\section{Literature Review}

Slum environments are characterized by poor physical, economic and social conditions. There is poverty, inequality, lack of social discipline as well as the inability of regency government agencies to organize and deliver resources and services to informal settlements in accordance with the nature of the functions of the city. In urban areas, including cities in Indonesia, slums are becoming more numerous and causing a variety of problems.

According to the World Bank (2008) a slum environment is described as a neglected part of the urban environment where the living conditions and livelihoods of the people are tenuous, characterized by uninhabitable housing, high levels of population density, public facilities and sub-standard infrastructure, the unavailability of education and health facilities, as well as adequate social and cultural community facilities and infrastructure. Slum settlement occurs because poor people with no job, money or land have no other choice than to put up makeshift housing in marginal areas on the periphery of urban areas resulting in poor quality of life. Slums can be categorized as follows:

a) Squatter Settlement which is a slum area that has illegal occupants.

b) "Slum" which is an area that is low quality and lacks infrastructure. Such environments tend to deteriorate.

Relocation programs theoretically, are implemented. The World Bank (2008) recommends that before deciding on a relocation plan it is necessary to prepare a planning framework or a resettlement policy framework carefully. The relocation program for Bengawan Solo was developed on a participatory basis, so that resettlement decisions are made by the community themselves.

\section{Evaluation Approach}

In carrying out the evaluation, according to Dunn (2003) there are three approaches, which can be distinguished, based on the characteristics of the value of the system, namely:

1) Pseudo Evaluation: An evaluation approach that relies on information / data that is self-efficient and cannot be controversial, nor is it specifically related to a person's value system / group of people, and without trying to find out the benefits the value of a group or individual.

2) Formal evaluation: An evaluation approach that uses descriptive methods to produce valid and reliable information about the results of a policy that has been formally announced by policy makers / programs.

3) Decision Theoretic Evaluation (DTE) An evaluation approach that aims to produce reliable and valid information about policy / program results that are explicitly assessed by several types of policy actors.

The evaluation used in this study is an evaluation at the program level; the formal evaluation approach which is normally carried out after the program has been completed within a certain period of time. The evaluation is conducted with the assumption that proper indicators of the evaluation process were stated basing on the objectives and implementation factors being formally announced as an appropriate measure for evaluating programs.

Table 1: Evaluation Implementation

\begin{tabular}{|c|c|c|}
\hline $\begin{array}{l}\text { The planning stage } \\
\text { (ex-ante evaluation) }\end{array}$ & $\begin{array}{l}\text { Implementation phase } \\
\text { (On-going evaluation) }\end{array}$ & $\begin{array}{l}\text { Post implementation } \\
\text { (ex-post evaluation) }\end{array}$ \\
\hline $\begin{array}{l}\text { Done before the development } \\
\text { plan is determined }\end{array}$ & $\begin{array}{l}\text { Done at the time of } \\
\text { implementing the development } \\
\text { plan }\end{array}$ & $\begin{array}{l}\text { Done after the implementation } \\
\text { of the plan ends }\end{array}$ \\
\hline $\begin{array}{l}\text { To choose and determine the } \\
\text { priority scale of various } \\
\text { alternatives and possible ways to } \\
\text { achieve the goals that have been } \\
\text { previously formulated. }\end{array}$ & $\begin{array}{l}\text { To determine the level of } \\
\text { progress in implementing the } \\
\text { plan compared to predetermined } \\
\text { plans }\end{array}$ & $\begin{array}{l}\text { To see whether the achievements } \\
\text { (outputs / outcomes) of the } \\
\text { program are able to overcome } \\
\text { the problem that you want to } \\
\text { solve }\end{array}$ \\
\hline & & $\begin{array}{l}\text { To assess the efficiency (outputs } \\
\text { and outcomes compared to } \\
\text { inputs), effectiveness (outcomes } \\
\text { and impacts on targets), or } \\
\text { benefits (impacts on needs) of a } \\
\text { program }\end{array}$ \\
\hline
\end{tabular}

Source: William Dunn (2003) 


\section{Research Methods}

Based on the problem and the objectives to be achieved, this research includes applied research, namely research or investigation of a problem with the aim of using its findings for certain purposes (Nazir, 1988). With this type of research above, the appropriate research approach to determine the source of data in this study is to use an evaluation research approach (Evaluative Research) as stated above. The evaluation conducted in this study is a summative evaluation. According to Fisher and Scriven (1997) summative evaluations are carried out at the end of the program to provide information about the benefits and usefulness of the program. The method of data collection included: primary data collection, utilizing surveys by observation, questionnaires and interviews. Sampling for the questionnaire was done using random sampling.

\section{The Relocation Program in Bengawan Solo Riverbank Area}

The Bengawan Solo River Bank Relocation program was developed due to the fast-growing number of illegal houses along the riverbank area. This riverbank area is restricted as residential and therefore the people living in this area should be relocated to a new area that is better equipped for residential purposes according to the Master Plan. The riverbank area is classified as a disaster-prone area, which periodically gets flooded due to overflow of the Bengawan Solo River in rainy seasons. The flood of 2007, which affected most villages, inundated approximately 6,368 houses in 12 Kelurahan (Villages) and 3 districts of Surakarta where 1,571 houses were located around the banks of Bengawan Solo River. Pucangsawit is one Kelurahan in Surakarta, where the Relocation Program for 268 houses of the riverbank area was implemented (Bapermas, 2012). Most of the people were relocated and resettled in KelurahanMojosongo, distributed in 6 plots of residential locations in NgemplakSutan (112 houses), Solo Elok (89 houses), Donohudan (36 houses), Mipitan (8 houses), KedungTungkul (18 houses), and SabrangLor (5 houses).

Table 2: Number of Victims of Flooding Disaster as a Target for Relocation Program in Surakarta

\begin{tabular}{|l|l|l|l|l|}
\hline \multirow{2}{*}{ No } & \multirow{2}{*}{ Name of Village } & Location of flood victim & Total number of \\
\cline { 3 - 5 } & & Riverbank area & $\begin{array}{l}\text { Outside } \\
\text { Riverbank area }\end{array}$ & \\
\hline 1 & Ps Kliwon & 0 & 7 & 7 \\
\hline 2 & Joyontokan & 0 & 1129 & 1129 \\
\hline 3 & KedungLumbu & 0 & 133 & 133 \\
\hline 4 & Sudiroprian & 0 & 75 & 75 \\
\hline 5 & Jagalan & 0 & 991 & 991 \\
\hline 6 & Gandekan & 0 & 20 & 20 \\
\hline 7 & Jebres & 218 & 257 & 475 \\
\hline 8 & Joyosuran & 57 & 897 & 954 \\
\hline 9 & Semanggi & 339 & 194 & 533 \\
\hline 10 & Sangkrah & 294 & 248 & 542 \\
\hline 11 & Sewu & 363 & 222 & 585 \\
\hline 12 & PucangSawit & 300 & 624 & 924 \\
\hline & TOTAL & $\mathbf{1 5 7 1}$ & $\mathbf{4 7 9 7}$ & $\mathbf{6 3 6 8}$ \\
\hline
\end{tabular}

Figure1 shows the mechanism used for Relocation in Bengawan Solo Riverbank, as follows (Astuti,2012):

a Socialization of the targeted community, which was conducted by the Mayor of Surakarta. This action was aimed to give a general overview and to build up community knowledgeon high risk living on the riverbank area;

b ) Formation of the workgroup POKJA (Kelompok kerja) and Sub-POKJA of Relocation, which were formed as a response to the establishment of the Mayor's Act of 2007. The role of POKJA was preparing proposals, coordinating sub-POKJA and community in the implementation of the program and maintaining communication links with the local government. Sub-POKJA was $t o$ directly coordinate with $t h$ e community in $\mathrm{t} h$ e distribution of grants;

c) Data Identification of Grant Beneficiaries was conducted by POKJA and Sub-POKJA, followed by collecting administration requirements for receiving aid for relocation. The Relocation grants included grants for obtaining land for Rp12million; grants for new housing construction for Rp8.5million and grants for public infrastructure for Rp1.8 million.

d) Inquiry of Destination Land for Resettlement was done by sub-POKJA together with the beneficiaries in order to look for land $\mathrm{wh} \mathrm{i} \mathrm{h}$ was suitable for residential development a t a $\mathrm{n}$ affordable price. As a requirement for having grants for land purchase, the land should have a land title from the National Agrarian Bureau (BPN). 
e ) Proposal Preparation for Relocation Grants was c o m p le t ed by POKJA and Sub-POKJA a $\mathrm{n} d$ $\mathrm{s} \mathrm{u} \mathrm{b} \mathrm{m} \mathrm{i} \mathrm{t} \mathrm{t} \mathrm{e} \mathrm{d} \mathrm{to} \mathrm{the} \mathrm{City} \mathrm{Government} \mathrm{through} \mathrm{DKRPPKB} \mathrm{(this} \mathrm{is} \mathrm{the} \mathrm{organization} \mathrm{name} \mathrm{related} \mathrm{to} \mathrm{this}$ particular resettlement system and is a People's Welfare Office dealing with Women's Empowerment and Family Planning) for obtaining construction grants of Rp8.5 million for each house.

f) Building Destruction and Removal was conducted to free the riverbank area from any residential development. Some people were recycling some building materials to be reused in the construction of new houses in the destination area of relocation.

g) Self-help Housing Construction of houses in the destination area of resettlement land. The Government Working Unit provided urban infrastructure such as local street, sanitation system, electricity and water supply. Social programs were in the form of assistance in environmental awareness to the local community towards sustainable management of the area.

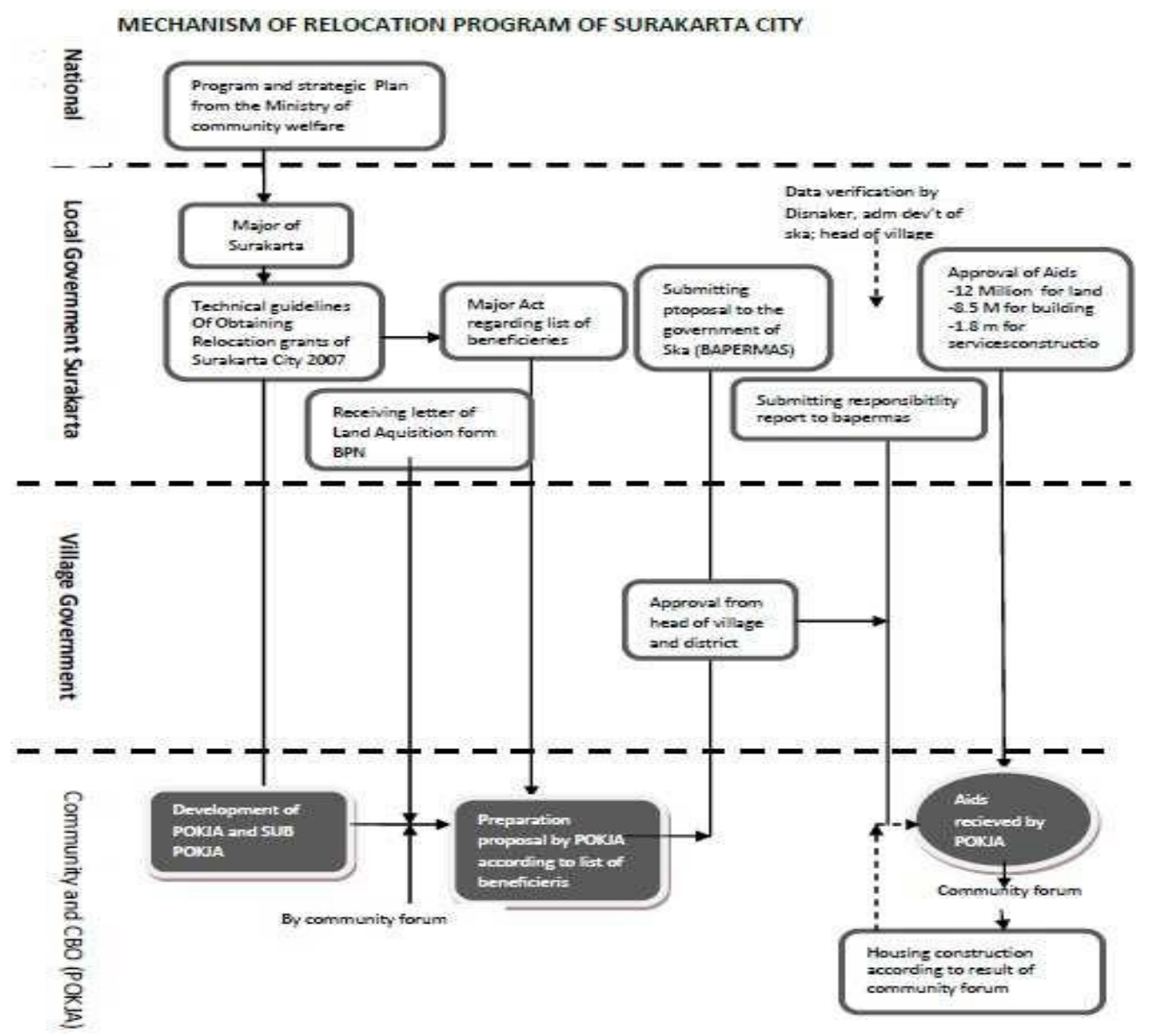

Figure 1: Mechanism of Relocation Program in Surakarta City

\section{Results of the Relocation program were as follows:}

1. This program has increased access to land and security of tenure for residential development; by providing the grants of Rp12 Million to each person in obtaining a parcel of land suitable for residential development, beneficiaries no longer stay on the hazardous area of flooding along t h e riverbank area with insecure residential status. Therefore, they are very happy and enthusiastic to obtain grants from the government and the overall process of program implementation. By land security in the form of formal tenure, the people have a right to effective protection by the state against forced evictions.

2. The program has increased access to adequate houses with affordable prices; by giving grants of Rp8.5 million for construction of new houses in the relocation area, residents now have adequate and more durable houses than their previous houses constructed along the river bank area. Thishelps in achieving the goal of poverty alleviation in terms of increasing access to land security with formal tenure and adequate houses with affordable prices. 
3. The program has improved the infrastructure in the neighborhood area; beneficiaries also received grants of Rp1.8million from the City Government for development of infrastructure in the neighborhood area through integrated management facilitated by the City Government. Infact, t h e relocation program has been successful in inviting and generating inter-organizational networks and integrated works among the Government Units, t h e private sector, community and NGO's and cooperative works for increasing neighborhood quality. BPN (National Agrarian Bureau) also known as The National Land Agency of Surakarta was issuing land certificates for land secure tenure in the new area; The Bureau of Local Public Services (BLUD,) Griya Layak Huni in the local language, helped facilitate warranties for people in obtaining housing mortgage loans from the bank for housing construction; PDAM (Water Supply Company) helped in distributing clean water supply services; PLN (National Electricity Company) has distributed electricity services; DPU provided infrastructure development; and DKP (Sanitary and Park Office) provided a local community park in the new area (see Figure2)

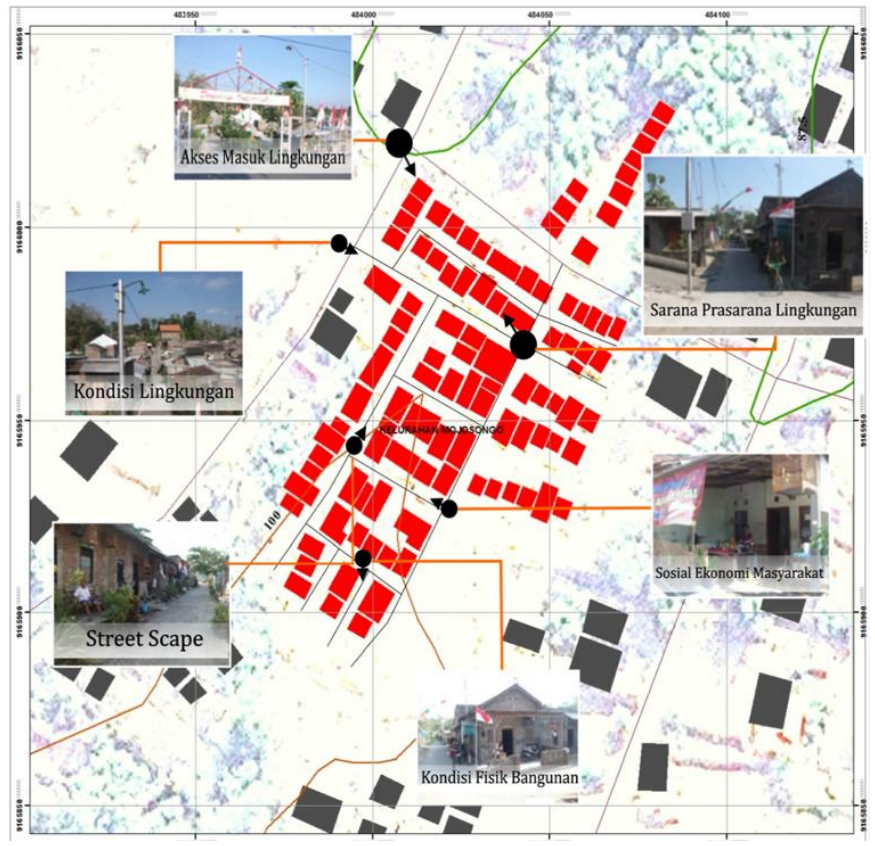

Figure 2 Benefits after Relocation

\section{The Impact of Relocation on Community Economic Conditions}

Changes in household economic conditions are one important indicator in explaining changes in the standard of living of people who are relocated. In the relocation program, The Asian Development Bank (ADB) revealed that one of the effects of relocation is the loss of productive resources, income and livelihoods. As one of the programs, relocation is expected to be able to provide benefits to the economy of the community in the new location. Indicators used to measure the economic impact arising from the relocation program are changes in the level of income and opportunities in obtaining sources of income. The following will describe the changes that occur in economic conditions based on these indicators.

\section{Income Level}

Income is a means to meet the needs and desires of the family household. The economic level of the people relocated is low. Most of the people work in the informal sector, namely, selling, rickshaw drivers, laborers and street vendors. Most of the people who were relocated work as laborers and hawkers. The hypothesis used is H0; Decrease in income before and after relocation is Not Significant and H1; Decrease in income before and after relocation is Significant. Based on the analysis using a statistical calculation of test marks assisted by SPSS Version 14 the following results are seen on table 3: 
Table 3Paired Samples Test Income Before and After Relocation

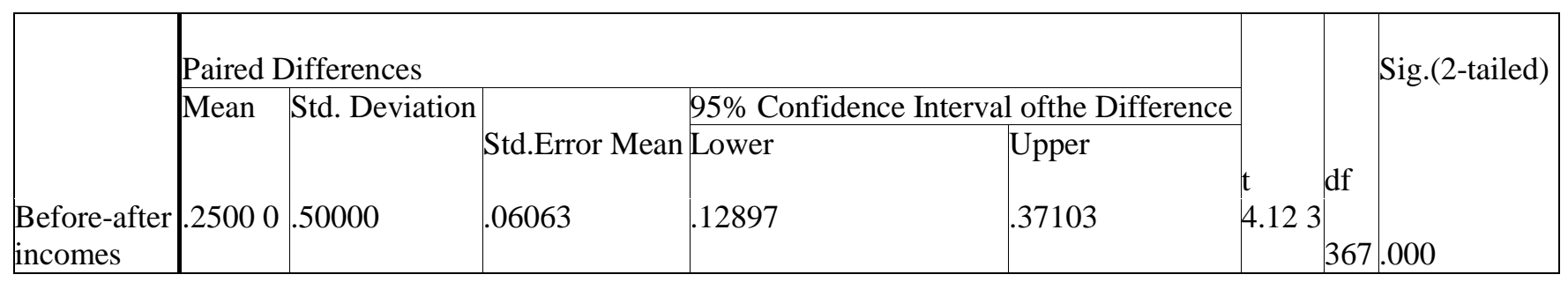

The results of the analysis above show the number of samples that experienced a change of income levels. Eighty-one respondents $(22.05 \%)$ experienced a decrease in income after being relocated, 286 respondents $(77.94 \%)$ said their income did not change; no respondent reported income had increased after being relocated. The test results also obtained a t-value of 4.123 (> 1.29), which means that there is a significant decrease in the level of income after being relocated. Thus it can be concluded that the relocation program carried out in the Bengawan Solo riverbank area has not been able to provide a positive impact on the level of community income, so in economic terms, the relocation program can be said to have been unsuccessful.

\section{Ease of Obtaining Sources of Income}

Post-relocation conditions before this study was conducted had not improved income and expansion of employment opportunities for residents in relocation settlements. This can be seen by the increasing number of respondents who find it difficult to obtain employment opportunities after relocation and decreased access to jobs in the new settlement location. See Table 4 below;

Table 4 Paired Sample Test Before and After Job

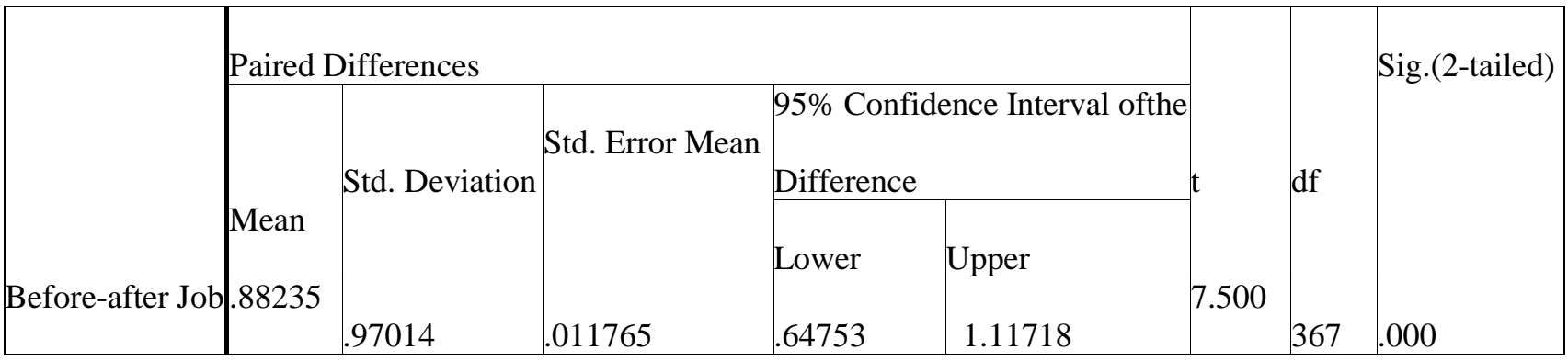

(Hypothesis used is H0: Decreasing opportunities to obtain sources of income before and after relocation is Not Significant; H1: Decreasing opportunities to obtain sources of income before and after relocation is Significant). The results of the analysis above show that there were 137 respondents who experienced a change in employment opportunities with 236 respondents experiencing a decrease in employment opportunities, 1 respondent experiencing an increase in employment opportunities, 31 respondents experiencing no change. From the test results also obtained t value of 7,500 (> 1.29), which means that there is a significant decrease in the ease of obtaining sources of income after being relocated.

Thus, it can be concluded that the relocation program carried out in the Bengawan Solo riverbank area had a negative impact on the availability / opportunity to obtain a source of income, and thus increased the level of difficulty in finding available jobs after being relocated.

\section{Synthesis of the Impact of Relocation on Community Economic Conditions}

From the two indicators used in assessing the impact of relocation on these economic conditions, the synthesis can be described as follows. Based on the table 5 below it can be seen that the relocation carried out on the banks of the Bengawan Solo did not result in a positive economic outcome for the community. Consequently, the relocation program carried out in Bengawan Solo riverbank was not successful in improving the economic conditions of the community after it was relocated. The lack of growth of the community in improving their economic conditions after relocation is due in part to the not yet established stability of the system and network of the community at the location of the new settlement within which they now live. The short duration of time between the implementation of this research and the completion of the relocation program may be a factor that causes changes in the economy to be less visible. 
However, the initial conclusions regarding the economic impact on the community after relocation can provide a valuable lesson to the city government in terms of finding timely solutions so that the location of their new settlements can continue to grow properly and not experience degradation which will likely result in increased slum-like conditions much like those that were experienced in the previous settlement.

Table 5Synthesis of the Impact of Relocation on Community Economic Conditions

\begin{tabular}{|c|c|c|c|}
\hline $\begin{array}{l}\text { Indicators of } \\
\text { economic } \\
\text { success }\end{array}$ & Discussion & Analysis Results & Conclusion \\
\hline Income level & $\begin{array}{l}\text { Assessment of changes } \\
\text { in income levels }\end{array}$ & $\begin{array}{l}\text { There was a significant decrease in the level of income after } \\
\text { being relocated. The relocation program has not been able to } \\
\text { have a positive impact on the level of community income, so } \\
\text { the relocation program can be said to be unsuccessful in } \\
\text { increasing income. }\end{array}$ & $\begin{array}{l}\text { Not } \\
\text { successful }\end{array}$ \\
\hline $\begin{array}{l}\text { Ease Within } \\
\text { Looking for } \\
\text { sources of } \\
\text { income }\end{array}$ & $\begin{array}{l}\text { Assessment of changes } \\
\text { in ease in obtaining } \\
\text { income source } \\
\text { opportunities }\end{array}$ & $\begin{array}{l}\text { There was a significant decrease in the ease of obtaining } \\
\text { sources of income after being relocated. Relocation programs } \\
\text { that have a negative impact on the availability / opportunities } \\
\text { to obtain sources of income are marked to increase the level of } \\
\text { difficulty in the availability of jobs after being relocated. }\end{array}$ & $\begin{array}{l}\text { Not } \\
\text { successful }\end{array}$ \\
\hline
\end{tabular}

\section{Conclusion}

From an economic perspective, the relocation program carried out on the banks of Bengawan Solo failed to improve the economic conditions of the relocated community. In summary:

- The income of the relocated community has not changed for the better, but rather has significantly decreased after relocation.

- The location of the new settlement has limited residents' ability to find opportunities in obtaining sources of income, as was reported by $48.53 \%$ of the people who were relocated

Conclusively as a whole, this paper highlights the mixed results of this relocation program. On one hand, resettled residents benefitted from home loans and other aid that permitted them to build new, more durable houses and obtain secure land tenure in the form of title, in addition to public services, such as electricity, sanitation, schools, a park and health centers. Evidently, the adverse impacts decrease in income and job opportunities. The question then becomes, how will they be able to repay their housing loans from the banks with less money? The point and lesson learnt here is that successful resettlement is not defined merely by obtaining land and a new house with all the amenities. Successful resettlement entails both land, new housing and amenities, but more importantly, a commitment to improving people's living standards/livelihoods so that the new communities can further develop. Emphasis should be on the importance of not just livelihood restoration, but improvement in order to stimulate future community development. The aim is to ensure that sustainable development is obtained and maintained so that the affected communities can be left better off than they were before they were relocated.

\section{References}

Astuti, W., et al (2012). "Model of Empowerment for Slums Community as a Main element of Community-based Housing Development (CBHD) - Case Study in Tipes Village, Surakarta City, Indonesia", Proceeding of the National Seminar of Green Urban Housing Policy, 4 th September 2012 Semarang, UNDIP Planology

Bintarto and Suprastopo.1987. Geographic Analysis Method. Jakarta: LP3ES

Bureau of Statistics of Surakarta City (2011). Statistical Data of Surakarta 2011

De Wet, Chris. 2002. The Experience with Dams and Resettlement in Africa. World Commission on Dams. South Africa: Cape Town.

Desmaniar, Lydia. 2009. Utilization of Quickbird Imagery and Geographic Information Systems for the Quality of Settlements in the Gondomanan District of Yogyakarta City. Thesis. Faculty of Geography, UGM: Yogyakarta

Dunn, William N. 2003. Public Policy Analysis: An Introduction, New. Jersey: Pearson Education.

Fisher, A., Scriven, M. (1997) "Critical Thinking: Its Definition And Assessment.". Edgepress And Center For Research In Critical Thinking: University Of East Anglia.

Nazir, M.1988. Research Methods. Jakarta: Ghalia Indonesia. 
PuputIchwatusSholihah\& Chen, Shaojun. (2018). Impoverishment of Induced Displacement and Resettlement (DIDR) Slum Eviction Development in Jakarta Indonesia. International Journal of Urban Sustainable Development, DOI: 10.1080 / 19463138.2018.1534737

Sujarto, Djoko. 2012. Planning for the development of a new city, Bandung: ITB Publisher

The World Bank (2002). Social Analysis Sourcebook

Turner, Bertha. (eds) (1987). Community Building. A third World Case Book - A summary of the habitat of the International Coalition Non-Governmental Organization's Project for the International Year of the Shelter of the Homeless. In association with the Habitat Forum Berlin

Uar, EkaDahlan. 2016. Strategies and challenges in handling slums in Ambon City. Journal of Fikratuna Volume 8 Number 2.

World Bank. 2008. Urban Poverty: A Global View. Washington DC: The World Bank Group. 